\title{
French Principals in Secondary Education: Towards New Roles and Responsibilities?
}

\section{Romuald Normand}

Université de Strasbourg - Faculty of Social Sciences (France)

UMR SAGE (Unité Mixte de Recherche - Sociétés, Acteurs, Gouvernement en Europe)

doi: 10.7358/ecps-2015-011-norm

rnormand@unistra.fr

\section{PRESIDI FRANCESI NELLA SCUOLA SECONDARIA: VERSO NUOVI RUOLI E NUOVE RESPONSABILITÀ?}

\begin{abstract}
The field of research on school leadership is not really developed in France. Professional literature dominates over research papers and the concept of management is not very popular among educators and academics. It is considered as connoted to business and to the market and opposed to the values of public services. French principals view themselves as "administrators» or "representatives of the State» and they are very concerned to apply national legislation and ministry's directives. Even if this notion is implicitly present within official instructions that define principals as "pedagogical and educative pilots» of schools, these executives lack real legitimacy to act on the teaching and learning issues which remain in the hands of State inspectors. So, leadership is recognized not as an official function, but rather through an implicit and blurred sense of professionalism expressed sometimes by professionals as "personal charisma», "sense of dialogue», "proximity». "Authority" and "responsibility" are the main social representations allowing principals to define their "missions» as public servants.
\end{abstract}

Keywords: Authority, Charisma, Leadership, Responsibilities, Secondary education. 


\section{INTRODUCTION}

Considered historically as administrators and representatives of the State, French principals face new responsibilities in the management of human resources and school leadership. If the notion of "chief" as in the French word "chef d'établissement" underlines the power of command and loyalty through a hierarchy inherited from the tradition of centralisation, the authority and personalization of power are replaced progressively by a more balanced vision of the sharing of responsibilities.

However, even if they are recognized in their pedagogical role, French principals are not, unlike in other countries, elected by their peers or recruited by local authorities. Principals have no power to recruit staff, their budgetary opportunities are strongly limited and they have to apply official instructions in the allocation of teaching hours related to a national and standardized curriculum.

The missions of principals have been settled through a compromise between the respect of national rules and the progressive affirmation of a local autonomy (Derouet, 1992; Delahaye \& Louis, 2006). Some changes occurred with the organisation of the secondary school system since the first Acts of devolution in the beginning of the 1980s. And today, if the school development plan remains the main component of school management, issues of evaluation are at the centre of policy-making.

The aim is to restructure schools according to the Act of finances (LOLF: Loi Organique d'Organisation des Lois de Finances) which introduces a logic of performance within the education system (Simler, 2003; Cytermann, 2006). The territorial governance of schools is affirmed while the cooperation between the primary and the secondary sectors are enhanced (Bouvier, 2007). Professional cultures and identities of principals are changing while they are moving away from a bureaucratic tradition.

It seems there are currently some opportunities to make principals the main agents of change at school level. But some challenges also remain: how to make each school, according to its local environment, a successful school? How to better involve teachers in working teams to improve student achievement? How to support initiatives and creativity among teachers? How to promote a culture of dialogue and cooperation within the school community?

French principals face these challenges in the management of secondary schools. Without ignoring the burn-out they face, this paper tries to provide some evidence on the main evolutions of the profession and to describe them through an international perspective: the paper begins with an historical outlook before drawing some main trends observed also in other European countries. 


\section{THE LONG MARCH TOWARDS DEVOLUTION AND AUTONOMY}

The role of the French principal in secondary schools has been defined through a long institutionalizing process. Indeed, French schools were long considered as mere recipients of the general policy of the French Republic, without any considerations for their autonomy. It is only during the 1960s that a new model of organization emerged according to the project of school democratization. Then, after the Acts of devolution at the beginning of the 1980s, a juridical status of Local Public Schools was created while the State continued to define duties and missions of principals.

\subsection{The devolution and the creation of the juridical status of public local schools}

The definition of headship as a profession depends largely on the variable idea of schools and their status developed in different periods of time. Several conceptions have come about in France over the last fifty years. A sort of sedimentation has been achieved and it will be described further to explain major current trends. Two moments were particularly at stake: the conference of Amiens, a city in the North of France, in March 1968, and the return of the Left to power in 1981. The Amiens conference focused on pedagogy and an agreement was reached among a large array of stakeholders from the idea of the school as an educative community. Other concerns during the 1980s were more directly political. The aim of policy-makers was to create a school unit at local level to create the possibilities of team work and to enhance the democratization of access to secondary education.

\subsection{The Amiens conference and the Act of 1968: the search for an agreement on the "Educative Community"}

At the end of the 1960s, a new model of organization emerged in which the conception of the school unit had to play a central role. The Amiens conference, in March 1968, sought for means to implement the national project of democratization: active pedagogies, softer relationships between teachers and pupils, a place given to arts and sports.

It was a claim among others. There were proposals to reorganize teaching and schools through Centres of Documentation and Information (CDI). Others were really focused on the welcome of working class and immigrant students as in the UK comprehensive school system. In challenging schools, 
some activists transferred the experience they had acquired in summer camps to open clubs and other meeting places. These initiatives were progressively organized and structured through the concept of a «Socio-Educative Home». This convergence, which can be considered today as heterogeneous, paved the way to the notion of the "Educative Community».

After the Amiens conference, the minister Alain Peyrefitte was eager to implement these recommendations, but his good will was challenged by the social protest of May 1968. However, the next minister, Edgar Faure, used this set of ideas to elaborate some new recommendations. The 1968 Act gave a juridical feature to secondary schools, through an administrative board, and it resumed the notion of "Educative Community» to give place to parents. At the same time, the Inspectorate of Schools was created and it was commissioned to supervise and control a new professional body of «education advisers».

René Haby (1973), the next minister of education, stopped this policy when took up office. He came quickly to a standardized conception of the lower secondary schools and introduced the idea of the "comprehensive school» inspired by the UK experience and the OECD (collège unique).

\subsection{From the creation of the French comprehensive school to the new status of secondary schools}

The reflection on the comprehensive school continued after the presidential elections won by the Socialist Party in 1981. Some reports were ordered to important thinkers in education: Louis Legrand, Antoine Prost, André de Peretti and then Pierre Bourdieu in 1985. Quickly, it was assumed that the pedagogical innovations for a "democratic lower secondary school» advocated at the beginning by Louis Legrand would not be formally accepted. While the Left was involved in a public controversy about the place of private education, Maurice Vergnaud, then the Head of the Directorate of Schools at the ministry, took over some progressive ideas and introduced the idea of the «autonomy» of schools.

This conception, presented as an experiment in 1982, became the centre of the governance of the education system according to the 1989 Act. But, before this date, the minister Savary, as his successor Jean-Pierre Chevènement, restricted the notion of autonomy to Education Priority Areas. For them, teachers had to take into account the local conditions of schools and to find some means to allow working class students to reach national standards. Alain Savary was very sensitive to the diversification of schools to satisfy the requirements of parents. He wanted to provide a quality of public education 
to discourage parents from turning to private schools. At this time, Robert Ballion, a sociologist close to policymakers, directed his attention to the emergence of school consumers.

After the Acts of decentralization, a decree was issued to create the juridical status of the Public Local Secondary Schools: it was a compromise between these heterogeneous and former orientations.

\subsection{From the school development plan to the contract of objectives}

The school development plan, since the decree of 30 August 1985, is the backbone of the management of secondary schools, as it defines the strategy of each school in relation to national guidelines ${ }^{1}$. The contract of objectives is signed with the State local authorities and fixes the objectives, while indicators are used to evaluate whether they have been met (Chudeau, 2004).

The school development plan is a collective process which presumes forms of cooperation not only managed but assessed (Bouvier, 2009). The contract of objectives, in responding to regional and national priorities, corresponds to programs of performance implemented by the ministry and defined in terms of benchmarks and indicators to meet.

\subsection{The school development plan: a framed autonomy}

Since 1985, through different decrees and circulars, legislation has reaffirmed the place of the school development plan in the contracts passed between the State local authorities and secondary schools. Each year, circulars explain that each principal can obtain some margins of autonomy in the development of the plan and through the organization of educative and pedagogical activities.

Some devices to diversify teaching and learning were created to valorise this autonomy. But, in fact, these new modes of organization did not reduce achievement gaps between students and they did not really change pedagogical practices in classrooms.

The authority conferred by legal texts to principals is not sufficient to affirm their pedagogical roles, while the divide between local governance and national policy, despite some improvements, is a main characteristic of the French education system (Toulemonde, 2006). The supervision of teaching is completely taken away from the principals.

1 Décret nr. 85-924 du 30 Août 1985, relatif aux «Etablissements Publics Locaux d'Enseignement». 
Beyond this institutional context, the implementation of the school development plan does not guarantee an effective reflexion and pedagogical innovation. Some plans remain very formal, more attached to the legal norms and the respect for procedures than to the quality of reflections among teaching teams.

No sufficient time is given to the design of this school development plan, to the cooperation between teams, to the definition of a strategy or to the search for solutions. The autonomy of schools should be better based on participative management supported by an evaluation process to provide relevant information and to help decision-making. It is the main condition for the school development plan to be understood and accepted by the educative community.

\subsection{The implementation of evaluation: a sort of formal ritual}

According to the implementation of new financial regulations in the French public administration, accountability became an inescapable reference for the action of public executives.

This logic of performance has often faced criticism: difficulties of measurement, technocratic drifts, wrong uses of indicators, competition between agents, etc. (Emin, Mons, \& Santana, 2003 and 2009). However, accountability was progressively imposed in the area of education through operational programs (PAP: Annual Programs of Performance, and BOP: Operational Budgets of Programs) related to the mission "Compulsory education" earmarked in the State budget.

Different objectives as indicators of performance are linked to areas of public action focused on the improvement of student achievement. A set of tools have been designed by the Directorate of Evaluation, Prospective and Performance (DEPP) while the use of indicators becomes a current practice among French principals. The inspectorate has also changed its mind about evaluation (Etienne \& Gauthier, 2004; Louis, 2010). If the visits of teachers in classrooms remain an important part of their mission, a lot of inspectors have used cross-inspections of schools and audits to analyse the management and the work of the staff (Lecointe \& Rebinguct, 1990; Lecointe, 1997). Several State local authorities have also developed experiments in leading external evaluations to support principals and their management.

The development of internal evaluation or self-evaluation of schools is considered as a complementary and useful approach by policy-makers and the inspectorate (Gather-Thurler, 2001 and 2002; IGEN - IGAENR, 2012; Normand, 2012). According to official guidelines, self-evaluation can contribute 
to the design and the management of the school development plan and to the dialogue with parents, students and school partners. The approach of selfevaluation is distinguished from the audit because it goes beyond the formulation of diagnostic and recommendations. It is also perceived as different from the traditional controls of legality and conformity previously carried out by the inspectorate. The Scottish experience served particularly as a reference to introduce self-evaluation of schools in the French context (Grek \& Ozga, 2011).

\section{THE RESPONSIBILITIES OF PRINCIPALS IN SCHOOL MANAGEMENT}

The responsibilities of principals are numerous and varied (Picquenot, 2004). Principals have an administrative responsibility when they apply laws and regulations, a social and civic responsibility when they talk with members of the educative community, organize elections of representatives in school and defend republican principles; and an educative and pedagogical responsibility in leading the school.

However, the more challenging responsibility is a juridical one. It is related to some risks faced by principals who have to remain vigilant to prevent any gaps regarding the law and to finely appreciate the possible consequences of their decisions and actions in courts.

\subsection{The risks faced by principals in taking on their responsibilities}

Even, if their action is narrowly framed by official instructions, principals have a moral responsibility in leading the affairs of the educative community. Most professional situations impose them to make some choices: they have to make a value judgment which requires respect for some deontology (Obin, 1996). From this point, the moral responsibility of principals is generally distinguished from their juridical responsibility. But they also have to manage some crisis situations.

\subsection{The weight of the law and the juridical insecurity of principals}

The irruption of the law into schools finds its roots in a relative decline of institutions (family, school, army, church, etc.) and of the sense of social and collective responsibility they could symbolize with regard to the past (Dubet, 
2002; Toulemonde, 2006). This crisis of legitimacy also concerns public educators and reinforces the mechanisms of responsibility and of trials in courts.

Three types of responsibilities are generally attributed to principals by official instructions (Mamou, 2004 and 2010). First, a disciplinary responsibility linked to their duties, which includes the respect for rules imposed by the hierarchical authority and the application of sanctions. Furthermore, principals face a civil responsibility for harm caused to people and goods, with a distinction established between the personal fault implying the civil servant, and the fault of service implying the responsibility of the administration. Then, they also have to be aware of their penal responsibility related to violations, offences, crimes and infractions (imprudence, negligence or inattention).

Even if trials in administrative courts remain limited for educational issues, legal proceedings against principals are largely commented by the media, particularly with regard to school trips and accidents. Today, trials are extended to the contestation of decisions about guidance, teachers and exams by parents.

The juridical insecurity of principals is enhanced by the relative uncertainty created by some ambiguous official instructions and by legislative inflation which makes it difficult to discern the borders of the application of the law. The prevention of violence has raised an abundant publication of circulars in creating security diagnostics, mobile teams, and school security correspondents while practices of dangerous games and bullying are under increased scrutiny (Mamou, 2010).

\subsection{Conflicts, violence, insecurity: the management of crisis situations}

Managerial experiences of crisis situations in schools have shown that the role of principals is essential to guarantee the authority of adults, but also to mobilize the educative community with regard to ethical rules.

From a pedagogical perspective, the reduction of violence and student aggressiveness requires some practices more focused on learning and formative assessment enhancing recognition and self-esteem instead of blame and sanctions which is the traditional way of solving conflicts by French teachers (Obin, 2001 and 2003). The management of classroom councils is also an important way for principals to improve the climate of schools and to listen to student voices. The facilitation of interdisciplinary and interactive teaching also creates more attention and motivation among students. Support for unsuccessful students by adjusted mentoring has been proved as a means of success. They largely depend on the action of principals. 
The involvement of adults in student care, the precise monitoring of attendance, the fixing of simple rules in the circulation between classrooms, and the regular reminder of internal rules are also some responsibilities expected from principals to maintain a sustainable peace. Principals have an important role in the educative area through dialogue with the educative community. Some devices can ben implemented to provide solutions for disturbing and drop-out students, to maintain good relationships with parents and to develop partnerships because they are solutions to limit conflict and violence. The involvement of parents prevents some behaviours at risk, particularly among adolescents, and it also a factor of school achievement.

\section{PRINCIPALS AS «PEDAGOGICAL PILOTS» OF SCHOOLS}

The juridical status on the autonomy of schools gives a pedagogical role to principals. Furthermore, a framework of skills defines areas of activities and skills required to lead schools through a pedagogical and educative strategy.

However, empirically, to analyse the pedagogical responsibility of principals, it is important to distinguish between their legality and legitimacy (Bastrenta, Normand, \& Nouis, 2013). The pedagogical management of principals is legally related to the organization of teaching, but not to its methods and contents. This responsibility takes place through a division of labour between the administration, the year head and his/her team (the «vie scolaire») and the area of pedagogy (teachers). Furthermore, each principal has to build his/her legitimacy close to teachers, parents and students.

\subsection{A pilot between administration, "vie scolaire» and pedagogy}

Beyond the school development plan, principals have to define the pedagogical structure for the current school year, particularly through the use of a Global Hours Dotation; a global and administrative budget fixing the distribution of teaching hours at school level. This pedagogical responsibility gives them the power to allocate teaching services, to build teaching teams, to organize official meetings between teachers, and to appoint head-teachers (De Saint-Do, Henry, \& Pointere, 2010).

Hence, principals can influence the pedagogical climate of the school and the way teaching activities are structured during the school year. Even if they do not assess teachers in their pedagogical practices, they have the right to visit them in classrooms, but they do not do this frequently. However, they 
talk with inspectors before and after individual classroom visits and they can be informed about courses in checking the contents of lessons written down by teachers in a "diary notebook» required by official instructions.

Finally, principals have a role in the regulation and harmonization of student assessments through their chairing and stimulus of classroom councils. In guidance, they are required to limit retentions and drop-outs, to organize dialogue with parents. In the "vie scolaire» (educative area), the principal, with the help of the year head, has to enforce rules and discipline, and to control student attendance, but this educative action also concerns the security and health of students, the maintenance of democratic life, and the organization of artistic and cultural activities.

\subsection{Leading the pedagogical council for school improvement}

The creation of the pedagogical council by the Act of 23 April 2005 can be considered as progress in the recognition of principals' pedagogical responsibilities.

This council, which has only a consultative role, reflects on the school development plan. It is considered by policymakers as a relevant device to improve the transversal coordination between teachers, to facilitate team work, to better support students, and to harmonize rules and methods of assessment (Matringe, 2005).

A great many schools have used the pedagogical council as a lever to innovate. However, the role of principals is decisive to build an agreement on common principles and to implement a dynamic of change.

The pedagogical council does not replace the other councils in schools (administrative council, classroom councils, etc.) and it does not challenge the "pedagogical freedom» of teachers and the role and legitimacy of inspectors in school subjects. It is an instrument to serve the school development plan and a sort of «laboratory of ideas» to improve the collective and pedagogical action in schools for better student achievement.

This council should normally be neutral and distant from trade unionist interests and not be concerned by the general management of the school. It could be the first step for an internal evaluation of the school development plan and it could help the reflection on training needs and support of teachers. But this is not currently the case and it remains largely formal in the reflections and discussions between teachers. In fact, there is a huge gap between these political intentions and the daily realities of schools. 


\section{SOME POTENTIALITIES TO DEVELOP NEW TASKS FOR FRENCH PRINCIPALS: INTERNATIONAL PERSPECTIVES}

The extent of roles and responsibilities of principals are varied in European countries. Differences can be expressed in terms of autonomy and educative/ pedagogical management, distribution of power in school boards, possibilities to recruit teachers, definitions of curricula, weight of local authorities, etc.

Despite these differences, a common trend can be observed at international level (Pont, Nusche, \& Moorman, 2007). The bureaucratic administrator or the head-teacher primum inter pares is replaced by a professional with new missions: greater responsibility in the supervision and evaluation of teachers, their professional development and team work; a new activity of accountability; a more strategic management of human and financial resources; and a more extended action outside schools, particularly through networks.

\subsection{Towards a new share of roles and responsibilities}

The devolution of more autonomy to schools does not guarantee the improvement of student achievement. It depends on how the share or roles and responsibilities is organized between the leading team and the pedagogical team.

To be effective, the management has to support a dynamic transformation and a continuous improvement of professional practices. The principal is a main actor of change in schools. S/he helps members of the educative community in creating a favourable climate to enhance professional cooperation and team work.

But these evolutions require an important transformation of the school organization, particularly through the creation of intermediary functions to assist principals in their daily management.

\subsection{The development of intermediary functions in schools}

Beyond official instructions regulating the "pedagogical and educative» management of principals, the role of the deputy head as an intermediary between the principal and teaching teams is as essential as the role of the "year head" (Régis, Serazin, \& Vitali, 2000; Grellier, 2009). Other modalities of middle management can be observed in French schools: coordinators of school subjects, head teachers and teachers in charge of a particular task or project. In Education Action Zones, which replaced Education Priority Areas, a function of coordinator has been created to coordinate and regulate innovations adapted 
to unsuccessful students. However, this sharing of roles and responsibilities, even prescribed by official guidelines, varies from one school to another.

Other countries have moved far away from this division of labour (Muller \& Normand, 2013). Pedagogical advisers have been created. Some teachers are involved in activities of training and evaluation outside their classroom. They support their young colleagues or they develop tasks to facilitate and manage innovations and projects. Some of them act as middle managers to help the leading team. Outside schools, some experienced teachers are consultants, experts, trainers, etc.

Of course, this restructuring of the teaching force impacts on the recognition of qualifications, on representations related to the profession, on careers, and sometimes on pay. But schools, and particularly students, are better supported while activities are more interactive and members of the educative community can develop exchanges and cooperation.

This «leadership» does not concern only English-speaking countries (Normand, 2010). It is a conception of «concerted», «shared» and «distributed» leadership which entails a change in the organization of schools. It is different from the sharing of roles and responsibilities defined according to a person, a status or a hierarchical or authoritative position, while it is based on social relations and capacity building.

\subsection{Support for the professional development of teachers}

Starting from this new sharing of roles and responsibilities, the management can transform the school organization in exploring new potentialities.

In dynamic schools, pedagogical teams have to permanently reinvent their methods to help students for better achievement. The role of principals is essential to maintain a climate of trust, but also to sustain the cooperation directed towards school improvement. Each teacher is recognized in his/ her expertise and contribution to the school development plan and can also profit from the transfer of knowledge and experiences from colleagues.

These horizontal relationships build the professional development of teachers and reinforce their belonging to the educative community (Normand \& Derouet, 2011). At the international level, professional development becomes an important way to manage schools. Principals are more and more involved in the coordination of training for their teaching teams.

Professional development helps teachers to face their diverse experiences and to systematically study their teaching: workshops, meetings between peers, mentoring, but also reading and discussions on research findings. Is it a long-term process which involves teachers through a continu- 
ous and sustainable reflection on their professional practices (Paquay, Van Nieuwenhoven, \& Wouters, 2010). The teaching staff is supported by one or more external experts who bring the required resources to transform their professional culture (Charlier \& Biémar, 2012).

However, some obstacles have to be overcome. The role of principals is decisive: it depends on whether they develop an administrative management reinforcing traditional habits or agree to take risks and to challenge professional practices. The professional culture of schools, be it conservative or innovative, influences the overall process of transformation.

\subsection{Working through networks: the emergence of new skills}

Working outside schools is one of the new skills expected from principals. The collaboration with other schools, the formalization of networks, the sharing of resources are recognized as important ways to improve student achievement. They are also ways to enhance professional development among teaching teams.

This articulation between initiatives and resources among practitioners and schools, based on shared objectives of improvement, is commonly called «systemic leadership». It means that different transversal roles and coordinative structures are defined and implemented to increase the effectiveness of local governance.

It has some consequences in the development of skills of principals. The objective of local authorities and policymakers is to facilitate lifelong learning better linked to situations of work and to actualize professional knowledge through peer learning activities.

\subsection{A network of schools and school improvement}

Schools in France do not generally belong to networks, but in other countries networks are linked to a new form of local governance.

At a local level, there are some institutional networks in the sense that principals coordinate their action according to the policy defined by the superintendent, and they can also share some information to regulate provision and guidance in a specified territory. However, French principals are not inclined to using social networks in order to exchange practices and professional knowledge (Pauly, 2012).

Despite this, in Education Action Zones, networks have been set up and it changes the borders of management in providing a coherent frame- 
work for the school development plan and pedagogical innovation (Armand, 2012). Beyond this sectorial policy gathering together local authorities, associations and other partners, a network between schools is not very focused on pedagogy and exchanges between teachers on their practices.

However, the literature has produced evidence on the effect of networking on student achievement. An effective network offers opportunities for exchanges with the support of external expertise and it gives some possibilities to evaluate actions and their effects. However, it should be focused on school improvement and support teaching teams through a new distribution of roles and responsibilities within schools.

In this configuration, principals can develop partnerships between schools: a shared conception of curricula, common innovative programs and work on guidance and inclusion, transversal devices to support unsuccessful students. Each principal potentially becomes a companion of another colleague who faces more difficulties and can share his/her knowledge and professional experience.

\subsection{Think global, act local: towards a new professional culture?}

As already said, principals have an important role in the success of schools, in supporting teaching teams and in building a culture of cooperation among teachers, as in the development of a regular evaluation linked to the school development plan.

As administrators, principals have to respect regulations and achieve targets fixed by local authorities. As leaders, they organize teaching activities and lead the change to enhance student achievement. More and more, they take into account the school environment in developing a systemic approach through networks and partnerships.

These transformations of the profession requires new skills (UNESCO, 2006). Principals are successively: guides when they solicit the participation of teachers to multiply opportunities for interaction and exchange; facilitators when they build teams and seek resources for them; evaluators when they gather data on their school to guide their management; coordinators when they organize teaching or allocate services and classrooms; planners when they try to share a vision, determine objectives and plans; mediators when they meet teachers and other agents to solve problems and conflicts; innovators when they promote creativity and school improvement.

It requires new approaches of training to better take into account the true conditions of work, but also to support principals through their career. In-service professional development of principals is at stake for their profes- 
sionalization. It should include not only a good initial training, but also a continuous professional development based on observation and analysis of practices through peer learning activities inside professional networks.

\section{CONCLUSION}

The last two decades have seen the missions and functions of French principals change. The pedagogical dimension of their activities has been affirmed while their action gives more space to organizational issues and the sharing of responsibilities away from a bureaucratic vision.

The shift from an administrative organization to an autonomous school involved in networks corresponds to a long-standing evolution in Europe. This transformation of schools entails some redefinitions of professions in education and it gives more space to intermediary functions between administration and the classroom through support and evaluation of actions, pedagogical innovations and team work.

In France, tensions remain for principals in developing their educative and pedagogical responsibilities between the respect for national standards and the development of local autonomy, but also between the juridical securitization of schools and some risks they have to undertake in their management. Some uncertainties characterize the evolution of the profession which has to bear heavy tasks and does not earn such an attractive salary.

However, the status of French principals and their training are improving. Despite the excessive accumulation of legal texts and administrative requirements, each day they invent a new professional model which could be developed and structured in terms of standards and skills. Principals are the primary agents of the success of reforms, and they are essential in school improvement at a local level.

\section{REFERENCES}

Armand, A. (2012). Education prioritaire et réseau. Administration et Éducation: L'École et ses Réseaux, 4, 59-65.

Bastrenta, M., Normand, R., \& Nouis, A. (2013). Les pouvoirs du chef d'établissement: autorité, légitimité, leadership. Lyon: SCEREN - CRDP.

Bouvier, A. (2007). La gouvernance des systèmes éducatifs. Paris: PUF.

Bouvier, A. (2009). Du projet au contrat d'objectifs. Poitiers: CRDP Poitou-Charentes - SCEREN. 
Charlier, E., \& Biémar, S. (Eds.). (2012). Accompagner: un agir professionnel. Bruxelles: De Boeck.

Chudeau, R. (2004). Le pilotage par les objectifs dans le second degré: la contractualisation. Administration et Éducation, 104, 117-121.

Cytermann, J. R. (2006). L'architecture de la loi organique relative aux lois de finances (LOLF) dans les domaines de l'éducation et de la recherche: choix politiques ou choix techniques? Revue Française d'Administration Publique, 217(1), 85-93.

Delahaye, J. P., \& Louis, F. (2006). L'EPLE et ses missions. MEN, IGEN - IGAENR.

Derouet, J. L. (1992). École et justice. De l'égalité des chances aux compromis locaux? Paris: Métailé.

De Saint-Do, Y., Henry, M. A., \& Pointereau, D. (2010). Le rôle pédagogique du chef d'établissement. Nouvelles missions, nouveaux outils. Paris: Berger-Levrault.

Dubet, F. (2002). Le déclin des institutions. Paris: Seuil.

Emin, J. C., Mons, N., \& Santana, P. (2003). Piloter par les résultats [Dossier]. Administration et Éducation, 98.

Emin, J. C., Mons, N., \& Santana, P. (2009). Le pilotage par les résultats. Un défi pour demain. Poitiers: SCREREN - CNDP - ESEN.

Etienne, J., \& Gauthier, R.-F. (2004). L'évaluation des collèges et des lycées en France: bilan critique et perspectives en 2004. MEN, IGEN - IGAENR.

Gather-Thurler, M. (2001). L'autoévaluation de l'établissement scolaire comme moteur de changement. In M. Bois, Les systèmes scolaires et leurs régulations (pp. 31-49). Lyon: CRDP (2002). Retrieved from: http://www.unige.ch/ fapse/SSE/teachers/gather-thurler/Textes/Textes-2002/MGT-2002-01.html.

Gather-Thurler, M. (2002). L'évaluation des unités d'enseignement: pour une démarche méthodologique et déontologique. In M. Bois, Les systèmes scolaires et leurs régulations (pp. 31-49). Lyon: CRDP.

Grek, S., \& Ozga, J. (2011). L'autoévaluation des établissements scolaires en Ecosse. Éducation et Sociétés, 28(2), 77-91.

Grellier, Y. (2009). L'adjoint au chef d'établissement scolaire. Direction etablissement. Lyon: SCEREN - CRDP du Centre.

IGEN - IGAENR (2012). L'évaluation des unités d'enseignement: pour une démarche méthodologique et déontologique. MEN.

Lecointe, M. (1997). Les enjeux de l'évaluation. Paris: L'Harmattan.

Lecointe, M., \& Rebinguct, M. (1990). L'audit de l'établissement scolaire. Paris: Editions d'Organisation.

Louis, F. (2010). Promouvoir une culture de l'évaluation et du pilotage dans notre système éducatif. IGEN, IGAENR, ESEN. 
Mamou, G. (2004). Pour un chef d'établissement, qu'est-ce qu'être responsable? In A. Picquenot (Ed.), Responsabilités: vers une thématique, vers une problématique (pp. 65-88). Dijon: CRDP de Bourgogne.

Mamou, G. (2010). Livre bleu «Les personnels de direction». Tours: SCEREN - CRDP du Centre.

Matringe, G. (2005). Le conseil pédagogique dans les EPLE. MEN - Inspection Générale.

Muller, F., \& Normand, R. (2013). La grande transformation de l'école? Les clés du changement. Paris: ESF.

Normand, R. (2010). Le leadership dans l'établissement scolaire: un nouveau partage des rôles et responsabilités entre chefs d'établissement et enseignants. Administration et Éducation: Piloter le Premier Degré, 125, 188-195.

Normand, R. (2012). L’auto-évaluation pour accompagner l'expérimentation et le projet d'établissement? Quelques pistes à partir d'expériences anglo-saxonnes. Education and Formations, 81, 67-75.

Normand, R., \& Derouet, J. L. (Eds.). (2011). Évaluation des élèves, développement professionnel des enseignants, et transformations de l'organisation scolaire. Réflexions autour d'expériences anglo-saxonnes [Dossier]. Revue Française de Pédagogie, 174, 5-11.

Obin J.-P. (Ed.). (2003). L'école contre la violence. Lyon: SCEREN - CRDP.

Obin, J.-P. (1996). Les établissements scolaires entre l'éthique et la loi. Paris: Hachette.

Obin, J.-P. (2001). Recommandations pour un établissement scolaire mobilisé contre la violence. Rapport pour le Comité national de lutte contre la violence à l'école. Lyon: SCEREN - CRDP.

Paquay, L., Van Nieuwenhoven, C., \& Wouters, P. (Eds.). (2010). L'évaluation, levier du développement professionnel? Tensions, dispositifs, perspectives. Bruxelles: De Boeck Supérieur "Pédagogies en développement».

Pauly, M. H. (2012). Pour des usages professionnels des réseaux par les personnels de direction. Administration et Education: L'École et ses Réseaux, 4, 115-120.

Picquenot, A. (Ed.). (2004). Responsabilités: vers une thématique, vers une problématique. Dijon: CRDP de Bourgogne.

Pont, B., Nusche, D., \& Moorman, H. (2007). Améliorer la direction des établissements scolaires, Vol. 2. Paris: OCDE.

Régis, R., Serazin, P., \& Vitali, C. (2000). Les conseillers principaux d'éducation. Paris: PUF.

Simler, B. (2003). LOLF et pilotage par les résultats. Administration et Éducation, 98, 129-136.

Toulemonde, B. (2006). Le pilotage pédagogique partagé dans l'EPLE. In M. Fort \& M. Reverchon-Billot (Eds.), Diriger, animer, piloter un établissement scolaire (pp. 157-160). Dijon: CRDP de Bourgogne - SCRERN - ESEN. 
Toulemonde, B. (2009). Droit et responsabilité dans l'institution scolaire. In C. Szymankiewicz (Ed.), Le système éducatif en France (pp. 20-25). Paris: La documentation française.

UNESCO (2006). Les nouveaux rôles des chefs d'établissement dans l'enseignement secondaire. Paris: Groupe inter-agences sur l'enseignement secondaire.

\section{RiassunTo}

La ricerca sulla leadership scolastica, in realtà, non è molto sviluppata in Francia. La letteratura di stampo professionale domina sugli articoli di ricerca e il concetto di "management» non è molto popolare tra gli educatori e i docenti universitari poiché si ritiene che sia collegato al mondo degli affari e del mercato e contrapposto ai valori dei servizi pubblici. I presidi francesi si vedono come "amministratori» o "rappresentanti dello Stato» e sono molto orientati all'applicazione della legislazione nazionale e delle direttive del ministero. Anche se questo costrutto è implicitamente presente all'interno delle indicazioni ufficiali che definiscono i presidi come le "guide pedagogiche ed educative» delle scuole, i dirigenti non hanno vera legittimità ad agire sulle questioni di insegnamento e apprendimento che restano nelle mani degli ispettori statali. Cosi la leadership non è riconosciuta nella sua funzione ufficiale, ma piuttosto attraverso un significato implicito e sfocato di professionalità espresso talvolta come "carisma personale», "senso del dialogo", "prossimità». "Autorità» e «responsabilità» sono le principali rappresentazioni sociali che consentono ai dirigenti di definire le loro «missioni» come dipendenti pubblici.

Parole chiave: Autorità, Carisma, Educazione secondaria, Leadership, Responsabilità. 